\title{
SOCIAL AND DIGITAL EMPOWERMENT OF VULNERABLE LIBRARY USERS OF THE MURCIA REGIONAL LIBRARY, SPAIN
}

\section{Empoderamiento social y digital de los usuarios en riesgo de exclusión de la Biblioteca Regional de Murcia, España}

\author{
José-Antonio Gómez-Hernández, Manuel Hernández-Pedreño and Eduardo \\ Romero-Sánchez
}
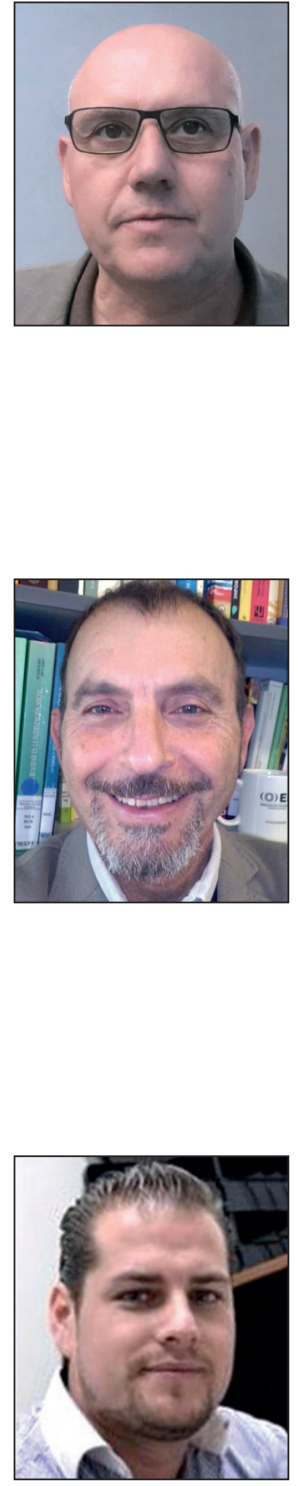

José-Antonio Gómez-Hernández, PhD in arts with honors and bachelor in contemporary history, has been a professor of librarianship since 1988 at the University of Murcia (UM), where he currently teaches on library management and on educational and cultural services. Previously he was the dean of the Faculty of Information Studies, director of Editorial and Cultural Services, and vice-chancellor of Communication and Culture. In his early career years, he worked as a librarian at UM. His publications include La información y las bibliotecas en la cultura de masas, Estrategias y modelos para enseñar a usar la información and Gestión de bibliotecas. http://orcid.org/0000-0003-4532-1142

Universidad de Murcia, Facultad de Comunicación y Documentación. Campus de Espinardo. 30100 Murcia, Spain jgomez@um.es

Manuel Hernández-Pedreño is a professor of sociology at the University of Murcia (UM), has a degree in economics and a PhD in sociology. He publishes frequently on inequality and social exclusion and especially on disadvantaged groups such as immigrants, women, youth, homeless persons, or persons with disabilities. He is the director of the Social Exclusion Observatory of the $U M$, and has participated in the project "European network of social quality indicators" promoted by the European Foundation on Social Quality. He has obtained the National research award 2015 of the Economic and Social Council of Spain for his study "Inequality, poverty and social exclusion: coordination and evolution of public policies in Spain".

http://orcid.org/0000-0001-5243-0481

Universidad de Murcia Facultad de Economía y Empresa, Departamento de Sociología Campus de Espinardo. 30100 Murcia, Spain manuel@um.es

Eduardo Romero-Sánchez has a degree and a PhD with honors in pedagogy from University of Murcia (UM), where he is professor of the Faculty of Education. He has been a visiting professor at the Institute of Education of the University of London, and at the Autonomous University of Baja California (México). Member of the research staff of the Social Exclusion Observatory of UM and pedagogical advisor of postgraduate medical education in primary care. His publications focus in two research topics: medical education and moral education.

http://orcid.org/0000-0001-5090-0961

Universidad de Murcia, Facultad de Educación Campus de Espinardo. 30100 Murcia, Spain eromero@um.es 


\begin{abstract}
This research is based on two qualitative techniques applied to further understand the levels of digital risk or empowerment of vulnerable users visiting Murcia Regional Library. Library users and staff, social workers, and the three most recent library managers were interviewed; participatory observation was applied. We studied the exclusion factors of users, their motivation for using library services, and their information and digital competencies. We conclude that these persons use the library primarily as a center for both leisure and media Internet purposes and also occasionally to study or job search. Nevertheless, and above all, they value the library as a comfortable, normalized, and inclusive space, in which they feel integrated and where, without limits, they can stay for leisure or practical purposes.
\end{abstract}

\title{
Keywords
}

Murcia Regional Library; User studies; Public library; Vulnerable users; Digital divide; Digital literacy; Digital inclusion.

\section{Resumen}

Para conocer el grado de empoderamiento o riesgo de exclusión digital de los usuarios en situación vulnerable que acuden a la Biblioteca Regional de Murcia se diseñó una investigación cualitativa basada en dos técnicas: la entrevista (a usuarios, a personal bibliotecario, a técnicos de entidades sociales y a los tres últimos directores de la biblioteca) y la observación participante. Estudiamos los factores de exclusión de los sujetos, sus motivaciones para utilizar los servicios bibliotecarios y su valoración de los mismos, así como su nivel de acceso a las tecnologías y su competencia digital. Se concluye que estas personas, aunque utilizan la biblioteca primeramente como centro de conexión a Internet con fines tanto de ocio como de comunicación y de estudio o búsqueda de empleo, valoran también la socialización que logran en la biblioteca como espacio confortable, normalizado e inclusivo en el que se sienten integrados y donde se desenvuelven sin limitaciones para fines lúdicos o funcionales.

\section{Palabras clave}

Biblioteca Regional de Murcia; Estudios de usuarios; Biblioteca pública; Usuarios en situación vulnerable; Competencia digital; Brecha digital; Inclusión digital.

Gómez-Hernández, José-Antonio; Hernández-Pedreño, Manuel; Romero-Sánchez, Eduardo (2017). "Social and digital empowerment of vulnerable library users of the Murcia Regional Library, Spain". El profesional de la información, v. 26, n. 1, pp. 20-32.

https://doi.org/10.3145/epi.2017.ene.03

\section{Introduction}

This work explains how the digital resources of the Murcia Regional Library (hereafter, the BRM), in terms of its social function, are used by those in vulnerable social situations. Such a social function, which is a given in public libraries, has been accentuated in the financial crisis years, with a notable increase in the number of economically and digitally precarious users. To accommodate and welcome them promotes the library as a place of integration and social cohesion.

The data indicates that, overall, in Spain, the number of library visits and of loans is beginning to descend. This has two general causes: On the one hand, the budgetary cuts for the acquisition of new books and the closures of some libraries and service points. On the other; changes in the manner of access and the usage of library products (especially audiovisuals), the amplification of intelligent telephones, and the considerable degree of connectivity of users with economic means. But, at the same time, there was considerable growth in the number of Internet sessions facilitated by public libraries such as portable computer loans and the unrestricted use of their wifi networks.

One is led to think the library is re-orientating its function. Although loans continue in importance, there has been a growth in interest for other services of a social, technological, educational, or cultural value. These services range from sojourns into empty spaces and study lounges; meetings and working groups; consultations; reading promotional activities; training workshops; loans of portable computers, chargers, calculators, and e-readers; and free Internet access. They are services which help people with services that they most need, keeping them connected and supporting their need for information, communication, and learning.

This evolution, due to the Financial Crisis and the growth of social inequality, has taken the course of access to information and technologies. While a broad sector of society intensifies its digital consumption with ample private connectivity, another sector lacks the resources for that and needs support from a public service such as the library so as not to be socially and digitally excluded.

This digital inequality makes obvious the various dimensions of this exclusion and the needs of the latter group of users. The objective is to adapt the services; contribute to the inclusive processes; to reduce, as far as possible, the digital divide defined as the new divisive factor which results, as much from the lack of access, as from the lack of capability for the efficient and meaningful use of information.

This analysis focuses on the BRM because it is the city's reference library. It is an accessible, prized building with modern installations, ample and comfortable spaces, and it is within a neighborhood of good public transportation servi- 
ce. It is always well attended and its generous open hours include Sundays (this was only until year 2012). Moreover, it has been implementing innovative social and educational programs in intercultural and employment mediums, such as Bivblioteca para todos ${ }^{1}$, Quitapesares ${ }^{2}$, Biblioteca Punto de empleo ${ }^{3}$, and Qué sabes ${ }^{4}$ (Gallo-León, 2008; CastilloFernández, 2010). When it was realized that, in recent years, some 700 people in the process of requesting a library card had indicated that their residence was a Murcian homeless peoples hostel (Gómez-Hernández, 2016), the Library's management agreed to investigate such users with the dual purpose of knowing the tasks necessary for the social and digital inclusion of these groups and to progress with implementation guidelines.

\section{Objectives}

The general objective is to analyze the information and digital behavior of the BRM users in vulnerable situations, contextualized between an inclusive library vision and a conceptual framework of their social exclusion. And more specifically, to:

- Know the effects of the Economic Crisis on the incorporation of vulnerable users into the BRM.

- Define the levels of access and usage of information and communication technologies (henceforth ICT) and to measure the degree of digital acquisition of the users at risk of exclusion.

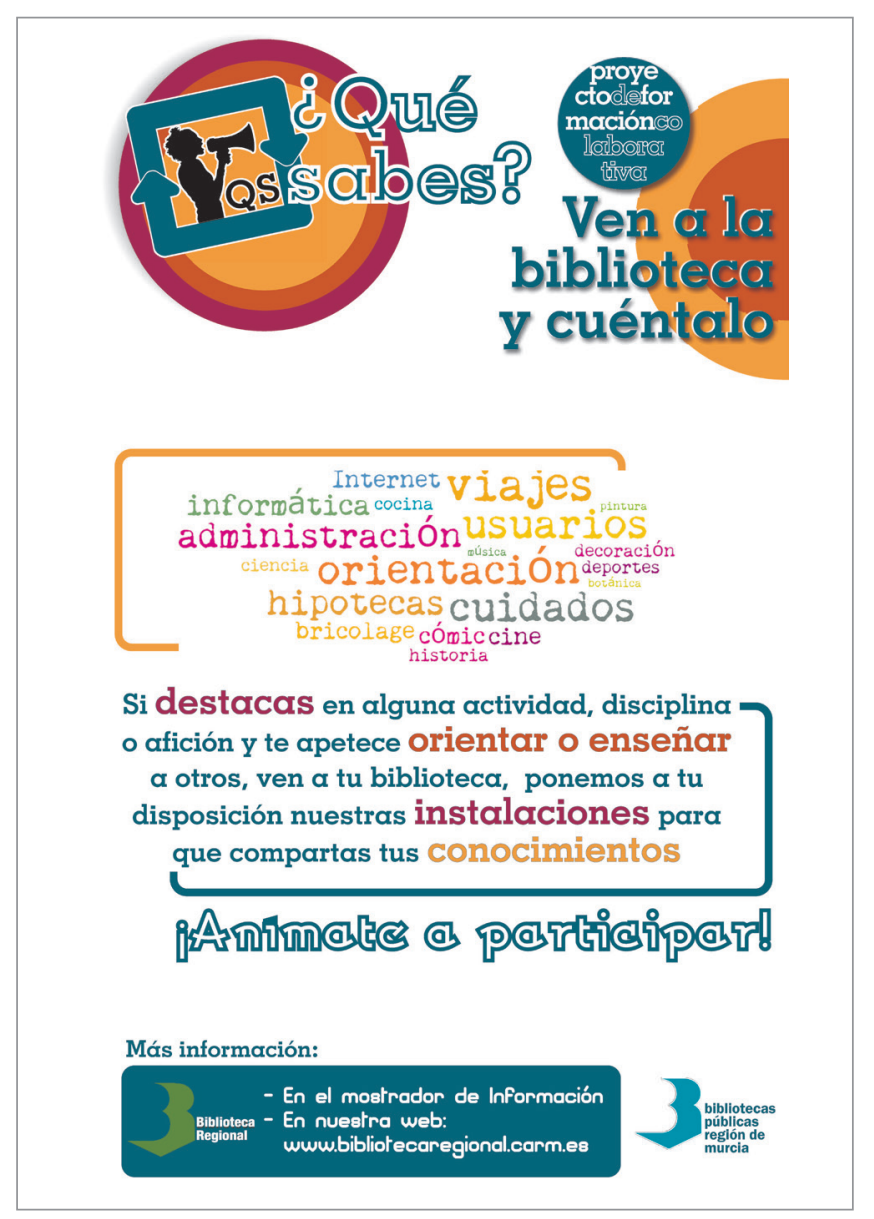

¿Qué sabes? program (see Note 4)
- Evaluate the relationship between the library services and the process of social and digital inclusion of such persons at risk of exclusion.

\section{Methodology}

The strategic methodology is based on two qualitative techniques: the semi-structured interview and participant observation, since they allow for the capture of the viewpoint of those who intervene in the social and cultural function of the BRM. Moreover, the state of this matter is reviewed beginning with the Annual report of the BRM, Library statistics (INE, 2015), and from Spanish public libraries in numbers (Ministry of Education, Culture and Sport, 2015).

Interviews were carried out on two types of agents associated with the usage of the $B R M$ and considered to be key informants: professionals and users. With respect to the first group, 17 were interviewed, among them professional librarians, information and loan desk assistants, and security personnel (referred to as TB1 to TB7 when quoted), the three most recent directors (D1 to D3), and two experts from social organizations which work with the population sector that is the object of this study (TES1 and TES2). In regards to the vulnerable users, nine with different degrees of social risk were interviewed (U1 to U9). Sub-categories of these nine were social risk (two of exclusion and seven of vulnerability -please refer to section 4.1 for a definition),

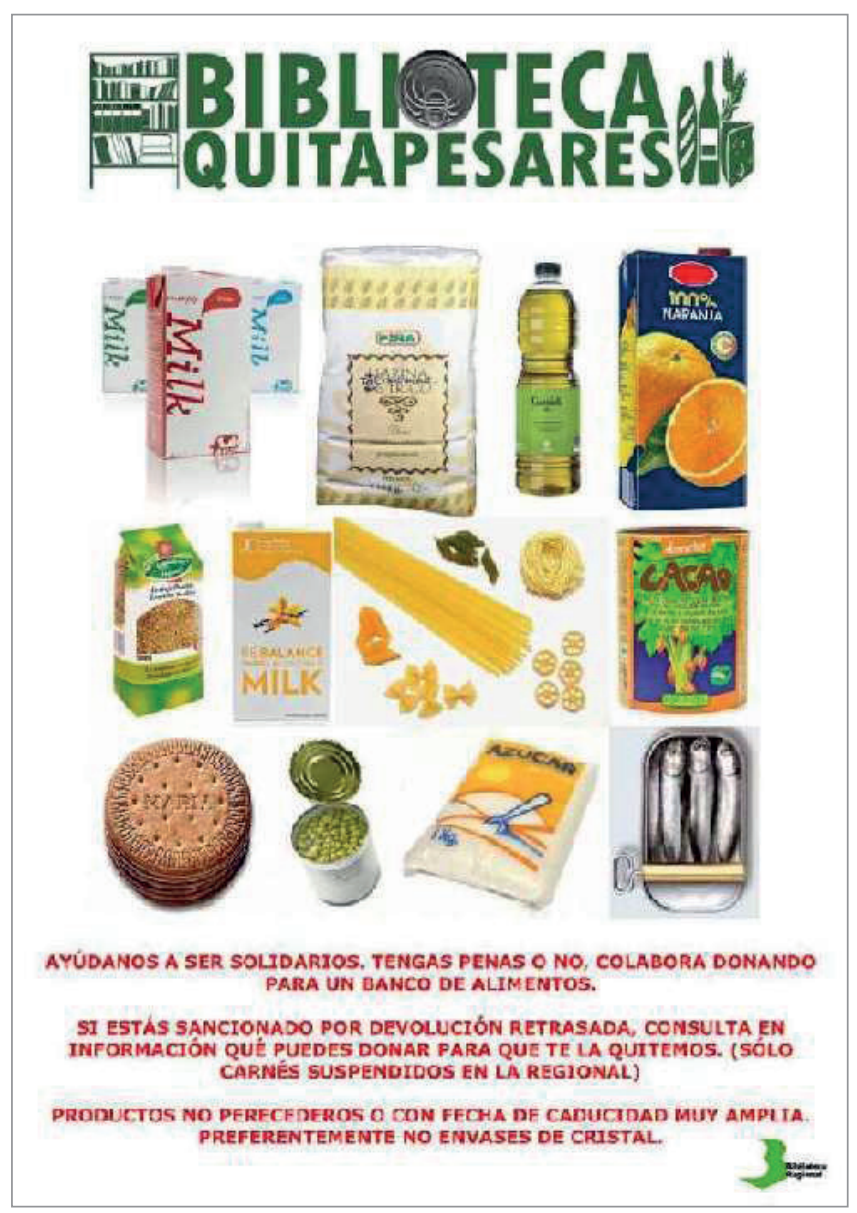

Quitapesares program (see Note 2) 
age (between 25 and 62), gender (six men and three women), and nationality (five Spaniards and four foreigners). The procedure followed in the interviews was semi-structured, and the interviews were carried out between February and June 2016.

Participant observations were carried out by nine students in the final year of their respective graduate courses in information $\&$ documentation science, pedagogy \& social work (01 to 09). Six were women (one was Moroccan and another Colombian) and three men. After receiving methodology training, the observation of participants was carried

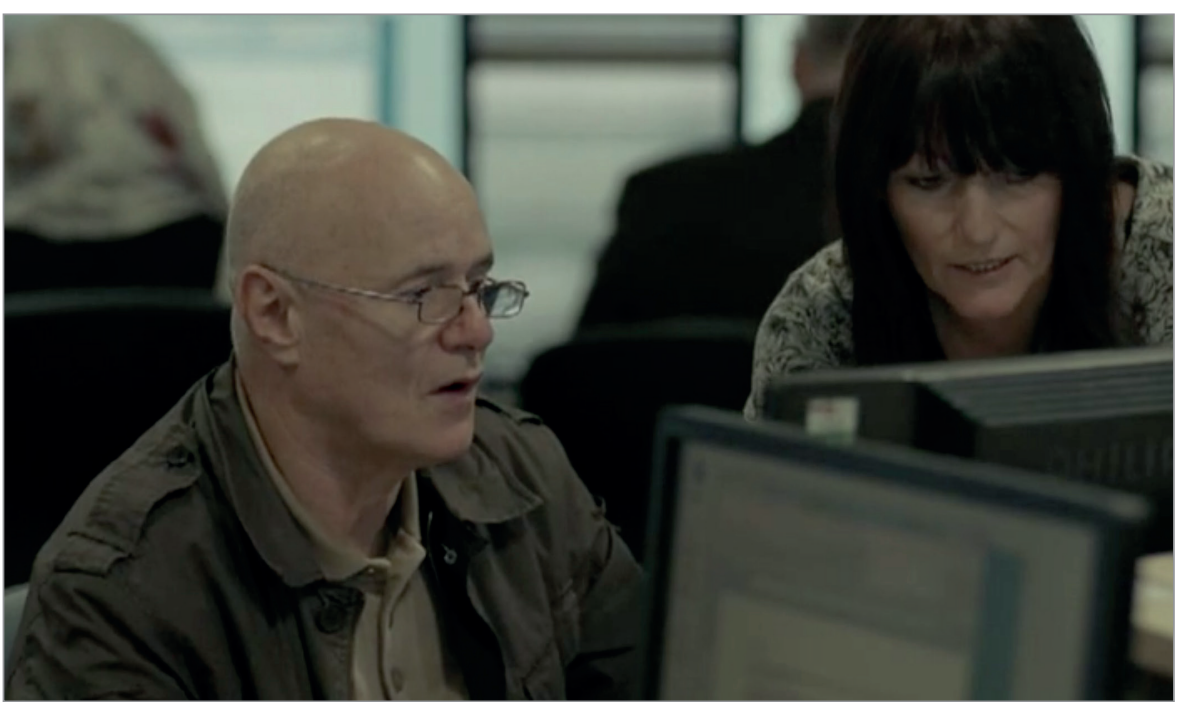

I, Daniel Blake (Ken Loach, 2016) https://vimeo.com/188997363 out from the $24^{\text {th }}$ to the $30^{\text {th }}$ of April 2016 during the $B R M$ operational hours. The observation type was passive (acting as anonymous users), with the exception of one of them (O7) who was an active participant, interacting to a large extent with users and experts in five distinct areas; the access zone or the entrance steps, the main hall (the control, information, press, and loan zone), the interior media hall (the computer and internet center), and the exterior media hall, an open one frequented by long-time regular users, pre-2008-crisis local residents. Other zones included restrooms, the children's room, and reference counter.

The lack of access and digital competence limits or precludes knowledge, communication, relationships, work, or the exercise of rights

\section{Theoretical framework}

\subsection{Social exclusion and the digital divide}

After the Economic Crisis of the 1970's in Spain the designation of "social exclusion" was used in sociology as a description of vulnerable individuals and groups, supplanting the previous concept of "poverty". The new focus better reflects the situations which make life with dignity difficult, and which must be viewed relative to scarcity of economic earnings (Subirats; Brugué; Gomà, 2002).

Social exclusion is defined as:

"structural, dynamic, multi-faceted, and multi-dimensional which includes an individual component and which is approachable by way of social policies. It occurs for structural reasons (such as economic and social changes which have been produced in technological societies), and not only through individual factors" (Laparra-Navarro et al., 2007).

It constitutes a process of distancing from a situation of so- cial integration, for the active exercising of citizen's rights, and is produced when people accumulate social disadvantages in a series of crucial domains or dimensions. It is a matter of a process rather than a stable situation and has at least three levels or stages. These range from:

- an integration situation (where work and social relations are strong) to a

- vulnerable situation (characterized by a precariousness relative to work and by the fragility of relational support) and then to

- an exclusion situation (of marked marginalization, of alienation, in which the most disadvantaged circulate) (Castel, 2004).

Seven dimensions of exclusion have been identified: economic, workplace, training, social health, residential, relational, and participative

Seven dimensions of exclusion have been identified (Hernández-Pedreño, 2008). These conform to personal and social trajectories and between them there exists a strong connection:
- economic
- workplace
- training
- socio-health
- residential
- relational, and
- participative.

Indeed, the weighty contribution of the ICT into all facets of life gives rise to an eighth dimension of exclusion: Technology or the "digital divide" which has been identified in the sociological domain by Raya-Díez (2007). As it's reflected in the film I, Daniel Blake (Ken Loach, 2016) the digital divide is a factor which increases vulnerability. This is because the lack of access and competence limits, or precludes, knowledge, communication, relationships, work, or the 
exercise of rights. For these reasons, it ought to be explored how they, digitally speaking, are on the edge in other social fields. The level of digital empowerment ought to be measured and understood so as to act on it. Its equalizing potential demands the exploration of the benefits, strengths, and opportunities for the population group at risk of exclusion.

Hence, technological exclusion is a dimension which, when overcome, can contribute to the reduction of the remaining causes of vulnerability -otherwise it can act to accentuate them-. And it is not only a matter of equipment (the possession of, or access to, a computer or a mobile phone), but also of digital or information technology competence so as to use it meaningfully and to profit from its possibilities in a reflective and intentional manner in accordance with one's personal or collective objectives.

This focus attempts to convert the information \& communicative technologies (ITC) into technologies for empowerment and participation (TEP) (Reig-Hernández, 2012) making possible the related resolution of problems and the necessities of an economic, employment, educational, family, affection, group or citizenry nature, from the merely functional level, to that of social transformation; incorporating values of solidarity, cooperation and equality (Pimienta, 2009; Gómez-Hernández; Saorín, 2015).

\section{Libraries enrich public space so as to convert it into "a second living room"}

\subsection{The function of libraries in social and digital in- clusion}

The concept of digital exclusion as a part of social exclusion is very close to the viewpoint of library science about the function of public libraries. From its origin, the public library has attempted to give equal access to information without barriers related to a person's economic, social, cultural, racial, political, nationality, gender, or religious status. It fulfills the educational and cultural functions currently prevailing and managed within the European Union for 65,000 libraries which some 100 million citizens frequent (Lison et al., 2016).

A very important factor is the availability of equipments and space for being open, free, accessible and comfortable. The library welcomes people of whatever status who can come together or interact, a facility that contributes to social cohesion. Like an agora or 'third place', it converts itself into a public plaza by democratizing social space with services which facilitate the cultivation of citizens for social, digital, employment, or, cultural inclusion (Gallo-León, 2013). Libraries enrich public space so as to convert it into "a second lounge room", a place attractive to people of all ages and social groups who revitalize the areas where they are seated, and where anyone can pass the time and utilize services (Lison et al., 2016).

IFLA (International Federation of Library Associations and Institutions) as the representative of libraries, has defended the commitment of the latter with the guarantee of access to information for everybody; thereby achieving through the Declaration of Lyon (IFLA, 2014a) that this right may be included among the goals of the 2030 Agenda for the sustainable development of the United Nations. Its concept about Internet access is expressed in the IFLA Internet manifesto (2014b). The document highlights the fact that libraries provide this service with comfort, orientation, and support, helping to overcome the barriers created by inequalities of resources, technology, and skills of individuals. It also advocates that the Internet should be open without ideological, political, or religious censorship, nor with economic or technological barriers, so that it may be attended by users in an appropriate ambience, regardless of age, ethnic origin, nationality, religion, culture, ideology, politics, physical or intellectual capability, gender, or sexual orientation. Likewise search competence to freely look for, use, and share confidential and independent resources should be taught, intellectual and cultural creativity promoted, as should be the economic aspect of always giving free access.

In Spain, the public library has augmented its inclusive function in response to the context of the Economic Crisis, in a time of cut-backs and questioning of public services. So as to justify their social and economic value, the return on investment in libraries has been investigated (Gómez-Yáñez, 2014), has been quantified in the Navarra Autonomous Community (Hernández-Sánchez, 2016) and, in a study of Barcelona Deputation, fifteen benefits of their function have been described and articulated along four axes and two perspectives (Togores, 2014) (Table 1).

Table 1. Social benefits of libraries (Togores, 2014)

\begin{tabular}{|l|l|l|}
\hline \multicolumn{1}{|c|}{ Axis } & \multicolumn{1}{|c|}{ Individual perspective } & \multicolumn{1}{c|}{ Community perspective } \\
\hline Cultural & $\begin{array}{l}\text { Promotion \& development of the habit of competent reading } \\
\text { Universal access to knowledge \& reading }\end{array}$ & $\begin{array}{l}\text { Preservation \& awareness of local cultural memory } \\
\text { Local cultural and artistic progress }\end{array}$ \\
\hline Social & $\begin{array}{l}\text { Social inclusion } \\
\text { Inclusion of disabled persons } \\
\text { Inclusion of cultural diversity }\end{array}$ & $\begin{array}{l}\text { Social cohesion } \\
\text { Social capital; inherited and developing } \\
\text { Revitalisation of public space }\end{array}$ \\
\hline Economic & $\begin{array}{l}\text { Promotion \& development of employment opportunities \& work- } \\
\text { place inclusion }\end{array}$ & Promotion \& development of local economic progress \\
\hline $\begin{array}{l}\text { Educational/ } \\
\text { Information } \\
\text { technology }\end{array}$ & $\begin{array}{l}\text { Development of IT (information technology) literacy } \\
\text { Resultant digital inclusion }\end{array}$ & Better-informed societies \\
\hline
\end{tabular}




\section{Results}

\subsection{Economic crisis and vulnerable users in the BRM}

The initial and evident effect of the crisis was the loss to the $B R M$ of mediums, materials, and personnel. According to the $B R M$ records, if the 2014 library purchases budget for the $B R M$ itself and for the municipal libraries of the Regional System is compared with that of 2008 we see that it reduces from $€ 1,763,360$ to $€ 116.584$.

BRM had 112 employees in 2010 (BRM, 2011) and by 2014 had lost 20 personnel from both the payroll and external services, resulting in a $22.5 \%$ reduction in human resources expenditure. The budget for equipment renewal, cleaning, and other externalized services also fell, requiring an enormous effort to maintain the quality of the services.

-Intercultural mediators who had been in the municipal libraries were laid off; that was rather hard... Service contracts were cut back, small booksellers who sold us books couldn't be paid... a big thing (D2)

-The Economic Crisis has been an influence because it curtailed the possibility of purchases and of innovation within the library. We haven't been able to develop certain very important projects. Our priority now is the arrival of money to switch on the lights... We have no budget for anything else, and that which is achieved, is done at zero cost (D1).

-The toilets are in a bad state and neither are they clean. The door handles don't close. Many toilets have no lid, nor is there toilet paper in many of them, and some hand basins are damaged (05, 06, Grouping: others, toilets).

In respect to the users, a $21 \%$ reduction in their visits has been observed as shown in the drop from 894,483 in 2008 to 706,976 visitors in 2014. Perhaps this was because of the scarcity of new materials or the Sunday closure. Despite this fall off, there was a growth in the number of people who visited because of their personal lack of resources, a situation of unemployment or vulnerability. These individuals study, learn, and use the wifi connection and computers to navigate the Internet (BRM, 2010). There are those who take advantage of the BRM's free entry, in so far as they find a normalizing space, to which they have frequent recourse, at the suggestion of the consultants of the social assistance centers.

-In 2008, there was an important boom in which people without resources came whether or not there was a crisis (TB2, comment on Media room).

-The crisis was markedly noticeable in the sense that before we had had a group of very regular foreigners and now we had many more and a lot of Spanish people who had no jobs (TB11, comment on Media room).

-The majority of the users for this service are foreigners of various nationalities (from Eastern Europe, Morocco, Latin America, Sub-Saharan Africa). They occupy spots which are at the back of the room; perhaps so that nobody can see what they were doing (02, Media screens room).

-First of all, these people when they are in the library are not on the streets. That is basic. That is to say, they are in a normalized place to which anybody can go and they are occupying their leisure and free time with something productive; they may be speaking with their family, they may be watching a film; whatever they are doing, they are not on the street (TES1, a social worker in a residence for the homeless).

\section{-When people are in the library and are} not on the streets, they are in a normalized place where anybody can stay (...). They are told 'When you go there, nobody knows if you are a person in a situation of exclusion or not' (social worker)

-They are told "You must go to the library. You must learn to move in other environments". There they can participate. "When you go there, nobody knows if you are a person in a situation of exclusion or not. You are at your computer, you are doing your things, and nobody knows what." It's even more anonymous. And, moreover, it is said: "Go to the library; put yourself on the Internet; practice ...". And so for us the library is one of those places about which we say "You must go to the library, get a library card." (TES1, social worker; refugee).

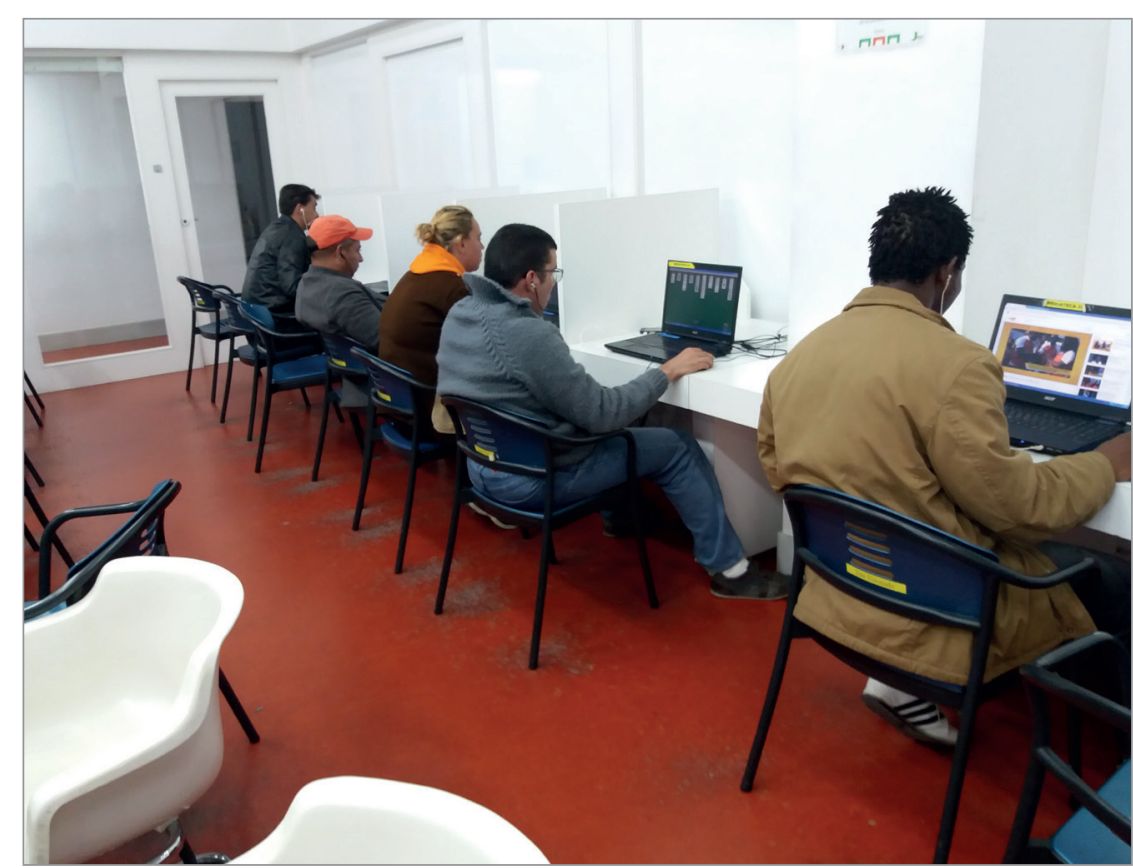

Computer and Internet Center (Interior Media Hall) 
Table 2. Categorization of levels of digital empowerment

\begin{tabular}{|c|c|c|}
\hline Indicator & Degree & Definition \\
\hline \multirow{3}{*}{ 1. Equipment and access } & Minimal & Basic mobile phone or PC, without data management \\
\hline & Sufficient & Basic mobile or smartphone $+\mathrm{PC}$ or portable at home but with limited connectivity \\
\hline & Complete & Smartphone or PC portable at home with total connectivity \\
\hline \multirow{3}{*}{$\begin{array}{l}\text { 2. Use and function of } \\
\text { information \& communi- } \\
\text { cation technology }\end{array}$} & Productive & Uses information \& communication technology (ITC) for training, work, and/or employment search \\
\hline & Leisure & Uses ITC and Internet for leisure activities (music, cinema, reading, sports, videos, videogames, etc.) \\
\hline & $\begin{array}{l}\text { Information \& com- } \\
\text { munication }\end{array}$ & Uses ITC and Internet to search for information, e-mail, relationships, social networks \\
\hline \multirow{3}{*}{$\begin{array}{l}\text { 3a. Domain of the five } \\
\text { dimensions of digital } \\
\text { competence }\end{array}$} & Basic & Only resolves simple digital tasks \\
\hline & Independant & Is familiar with, and uses, a range of tools and applies them to resolve problems \\
\hline & Competent & $\begin{array}{l}\text { Makes strategic and critical use of digital competence for a diversity of personal and social } \\
\text { purposes }\end{array}$ \\
\hline \multirow{3}{*}{$\begin{array}{l}\text { 3b. Global classification } \\
\text { of digital competence }\end{array}$} & Limited /dependant & Limited in confronting, autonomously with ITC and Internet, problems of daily life \\
\hline & Instrumental & Can resolve problems of daily life with ITC and Internet \\
\hline & $\begin{array}{l}\text { Innovator/Trans- } \\
\text { former }\end{array}$ & $\begin{array}{l}\text { Capable of improving one's daily individual or social conditions and of innovating with ITC and } \\
\text { Internet }\end{array}$ \\
\hline \multirow{3}{*}{ 4. Digital empowerment } & Deficient & Does not take advantage of most of the possibilities of digital proficiency for its vital purposes \\
\hline & Sufficient & Resolves personal needs through digital competence \\
\hline & High & $\begin{array}{l}\text { Profits from digital competence so as to improve one's personal conditions of life and social } \\
\text { participation }\end{array}$ \\
\hline \multirow{3}{*}{$\begin{array}{l}\text { 5. Potential consequenc- } \\
\text { es or risks of digital em- } \\
\text { powerment situations }\end{array}$} & Exclusion & Lacking the capability to access and profit from information and ITC for purposes of inclusion \\
\hline & Vulnerability & At risk of losing personal opportunities for lack of mastery of digital competence \\
\hline & Inclusion & Digital competence helps to improve one's personal situation and social integration \\
\hline
\end{tabular}

The number of loans decreased, dropping some $15 \%$ from 642,631 in 2008 to 548,388 in 2014. Instead, and to lend attention to the greater demand for Internet connection, the $B R M$ had to increase the number of ICT posts in the media zone up to 40 , acquire some portables and tablets so as to lend them for use within the premises, and to keep the wifi system permanently open without the necessity of identification.

-They come almost exclusively for the Internet. In a very short time, things have changed a lot. Two years ago we hardly had any spots for Internet connections. Now there only remain two spots for viewing films and all the rest are for Internet (TB7, Information).

-Here in the library, they also leave the wifi open on Sundays, so that many people can make use of it on Sundays in the doorways even though the doors are closed. I pass by and see people and at times I also make use of it. The library is close, but not everything is switched off. Always there is a window of opportunity for usage (U8, Moroccan immigrant woman of 44 years).

-It is surprising the good things which the BRM has preserved in the face of the impressively reduced budgets it has experienced. The fact is that there are good people working there and that by using their imagination they have continued pulling things out of the hat, at practicaIly zero cost (D3).

\subsection{Access, competence, and the degree of digital empowerment of vulnerable users}

Beginning with information gathered in user interviews, we analyzed their risk situation and digital empowerment to verify the relationship between the degree of access and digital competence, and the greater or lesser possibility of promotion or reduction of social exclusion factors.

\section{Digital competence}

Has been evaluated according to the European framework (Punie; Brecko, 2014), in accordance with which there are five dimensions, each of which can be experienced in basic, independent or competent degrees (Europass, 2015). They are:

- Information (to know how to search, to navigate, filter, evaluate, store, and recover information);

- Communication (to interact, share information and contents, participate, collaborate by means of digital channels, netiquette, and management of digital identity);

- Creation of content (develop content, integrate and reelaborate, be familiar with author's rights, licenses, and programming);

- Security (protection of devices, personal data and digital identity, health, and environment protection);

- Problem resolution (to resolve technical problems, identify needs and responses, innovate and make creative use of ICT; identifying competence gaps).

For the evaluation, five indicators, distinct from the five dimensions above, have been considered and are defined in Table 2.

- Equipment or access to technological resources.

- Declared uses of ICT and Internet

- Digital competence (situational and global)

- Degree of digital empowerment, and

- Situation of digital risk. 
Table 3. Evaluation of users' degree of digital empowerment

\begin{tabular}{|c|c|c|c|c|c|c|c|c|c|c|c|c|c|c|}
\hline \multirow[b]{3}{*}{$\mathbf{N}^{\circ}$} & \multirow{3}{*}{ Sex } & \multirow{3}{*}{ Age } & \multirow{3}{*}{$\begin{array}{c}\text { National } \\
\text { of }\end{array}$} & \multirow{3}{*}{$\begin{array}{l}\text { Social risk } \\
\text { situation }\end{array}$} & \multirow{3}{*}{$\begin{array}{l}\text { 1. Equip- } \\
\text { ment, } \\
\text { access, ICT }\end{array}$} & \multirow{3}{*}{$\begin{array}{c}2 . \\
\text { Use \& func- } \\
\text { tion of ICT }\end{array}$} & \multicolumn{6}{|c|}{ 3. Digital competence } & \multirow{3}{*}{$\begin{array}{c}\text { Digital } \\
\text { empower- } \\
\text { ment }\end{array}$} & \multirow{3}{*}{$\begin{array}{c}\text { Digital risk } \\
\text { situation }\end{array}$} \\
\hline & & & & & & & \multicolumn{5}{|c|}{ The five dimensions } & \multirow[b]{2}{*}{ Global } & & \\
\hline & & & & & & & $\begin{array}{l}3.1 . \\
\text { Informa- } \\
\text { tion }\end{array}$ & $\begin{array}{c}3.2 . \\
\text { Communi- } \\
\text { cation }\end{array}$ & $\begin{array}{c}3.3 . \\
\text { Content } \\
\text { creation }\end{array}$ & $\begin{array}{c}3.4 . \\
\text { Security }\end{array}$ & $\begin{array}{c}3.5 . \\
\text { Resolve } \\
\text { Problems }\end{array}$ & & & \\
\hline U1 & Man & 25 & Brasil & $\begin{array}{l}\text { Vulnerability - } \\
\text { Labour, } \\
\text { Economic Risk. } \\
\text { Foreigner }\end{array}$ & Complete & $\begin{array}{l}\text { Productive, } \\
\text { Leisure, In- } \\
\text { formation/ } \\
\text { Communi- } \\
\text { cation }\end{array}$ & $\begin{array}{c}\text { Compe- } \\
\text { tent }\end{array}$ & $\begin{array}{c}\text { Compe- } \\
\text { tent }\end{array}$ & $\begin{array}{l}\text { Indepen- } \\
\text { dant }\end{array}$ & $\begin{array}{c}\text { Inde- } \\
\text { pendant }\end{array}$ & $\begin{array}{l}\text { Indepen- } \\
\text { dant }\end{array}$ & $\begin{array}{l}\text { Transfor- } \\
\text { mer }\end{array}$ & High & Inclusion \\
\hline U2 & Man & 30 & Spain & $\begin{array}{l}\text { Exclusion, } \\
\text { Labour \& } \\
\text { Economic Risk, } \\
\text { also Health \& } \\
\text { relational }\end{array}$ & Minimal & Leisure & Basic & No & No & No & No & $\begin{array}{l}\text { Limited / } \\
\text { Depen- } \\
\text { dant }\end{array}$ & Deficient & Exclusion \\
\hline U3 & Man & 41 & $\begin{array}{l}\text { Domi- } \\
\text { nican } \\
\text { Republic }\end{array}$ & $\begin{array}{l}\text { Vulnerability } \\
\text { Labour, } \\
\text { Economic Risk. } \\
\text { Foreigner }\end{array}$ & Minimal & $\begin{array}{l}\text { Leisure, } \\
\text { Information } \\
\text { / Communi- } \\
\text { cation }\end{array}$ & Basic & Basic & No & No & No & $\begin{array}{l}\text { Limited / } \\
\text { Depen- } \\
\text { dant }\end{array}$ & Deficient & Vulnerability \\
\hline U4 & Man & 54 & Spain & $\begin{array}{l}\text { Vulnerability } \\
\text { - Labour, Eco- } \\
\text { nomic Risk .and } \\
\text { Relational }\end{array}$ & Minimal & Leisure & Basic & Basic & No & Basic & Basic & $\begin{array}{l}\text { Instru- } \\
\text { mental }\end{array}$ & Deficient & Vulnerability \\
\hline U5 & Man & 57 & Spain & $\begin{array}{l}\text { Vulnerability } \\
\text { Labour, Econo- } \\
\text { mic Risk. And } \\
\text { Health }\end{array}$ & Sufficient & Productive & $\begin{array}{c}\text { Inde- } \\
\text { pendant }\end{array}$ & Basic & No & Basic & Basic & $\begin{array}{l}\text { Instru- } \\
\text { mental }\end{array}$ & Sufficient & Inclusion \\
\hline U6 & Man & 62 & France & $\begin{array}{l}\text { Vulnerability } \\
\text { Labour, } \\
\text { Economic Risk. } \\
\text { Foreigner }\end{array}$ & Sufficient & $\begin{array}{l}\text { Productive, } \\
\text { Leisure }\end{array}$ & Basic & Basic & No & Basic & No & $\begin{array}{l}\text { Instru- } \\
\text { mental }\end{array}$ & Sufficient & Vulnerability \\
\hline U7 & Wom. & 41 & Spain & $\begin{array}{l}\text { Vulnerability } \\
\text { Labour, Econo- } \\
\text { mic Risk. Also } \\
\text { Residential and } \\
\text { Health }\end{array}$ & Minimal & Productive & Basic & Basic & Basic & No & No & $\begin{array}{l}\text { Limited / } \\
\text { Depen- } \\
\text { dant }\end{array}$ & Deficient & Vulnerability \\
\hline U8 & Wom. & 44 & Morocco & $\begin{array}{l}\text { Exclusion } \\
\text { Labour, } \\
\text { Economic Risk. } \\
\text { Relational \& } \\
\text { Foreigner also. }\end{array}$ & Minimal & $\begin{array}{l}\text { Information } \\
\text { / Communi- } \\
\text { cation }\end{array}$ & Basic & Básico & No & Basic & Basic & $\begin{array}{l}\text { Instru- } \\
\text { mental }\end{array}$ & Sufficient & Inclusion \\
\hline U9 & Wom. & 46 & Spain & $\begin{array}{l}\text { Vulnerability } \\
\text { Labour, Econo- } \\
\text { mic Risk. Also } \\
\text { Residential }\end{array}$ & Complete & $\begin{array}{l}\text { Productive } \\
\text { Information } \\
\text { / Communi- } \\
\text { cation }\end{array}$ & $\begin{array}{c}\text { Inde- } \\
\text { pendant }\end{array}$ & $\begin{array}{l}\text { Indepen- } \\
\text { dant }\end{array}$ & Basic & Basic & Basic & $\begin{array}{l}\text { Instru- } \\
\text { mental }\end{array}$ & Sufficient & Inclusion \\
\hline
\end{tabular}

The results are presented in Table 3.

These users usually have minimal equipment: a mobile phone that is not a smartphone or with limited connectivity, without a data contract and used only for calls. They do not have a computer or portable, or it is obsolete, and/or they are lacking Internet where they live. Even when they do have a computer or portable, they go to the BRM for its welcoming, relational condition and out of habit. The objectives of using the ICT in the BRM are diverse: to occupy leisure time, in some cases to study or seek employment, likewise to access information, email, and to connect oneself to social networks, in which, without being intensive users, they participate sporadically.

-I listen to music; I view Facebook and some film or other (U2, Spanish male, 30 years).

-On the Internet, I watch tennis matches. At times I come across them on Canal Plus TV, and as I don't have Plus at home, then I watch them here (U3, Dominican Republic male, 41 years).
-Before, yes, I chatted and now I also go into Facebook and I find someone from my family (U8, Moroccan woman, 44 years).

-On the Internet I watch topics that interest me like art and painting ... Games on the Internet are what I like most. That which hooked me are online games that you go into matched with another person and they are interactive (U6, French resident male, 62 years).

Digital competence (among such users) is usually elementary in information and communication tasks, and clearly insufficient in the resolution of problems, creation of content, and questions of security. Only in two cases was it considered to be at the level of transformer; in the rest it was of the instrumental type or limited and dependent. In the evaluation of access, use, and competence, it there was only one user in our study with a high level of empowerment, four with sufficient, and four deficient. In respect to the digital risk situation, we classified one as being in exclusion, four in vulnerability, and the other four in inclusion. 


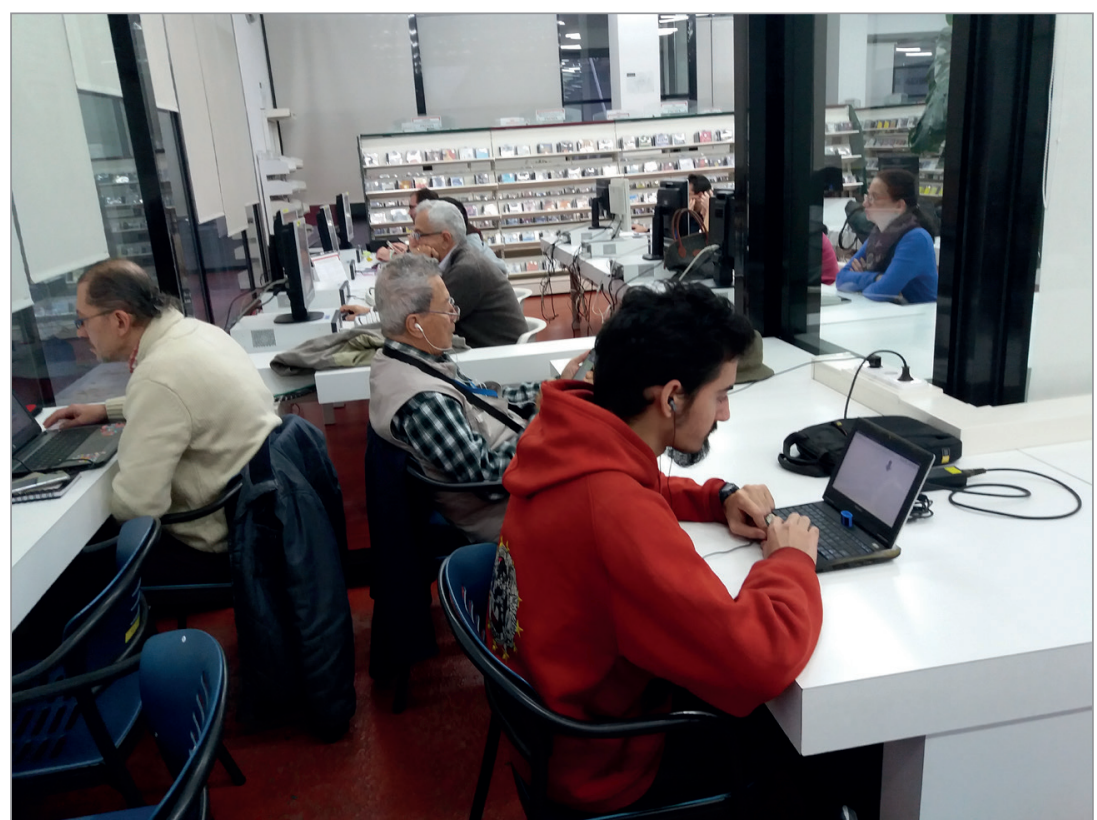

Computer and Internet Center (Exterior Media Hall)
Users with a greater level of digital competence use it to try and overcome their vulnerable situation, including pursuing studies, seeking employment, or preparing themselves to decide on employment posts. Their degree of digital empowerment contributes to reducing other factors of social exclusion, to facilitating relations and communication, access to information, and to training. Likewise, recourse to leisure is very necessary for people with a lot of free time, which they try to occupy in a gratifying manner.

-I am doing a course in office automation because in the exam for which I am preparing there is a test. And so I make use of the media room to be able to access the course, also I consult my electronic mail or consult the syllabus for which I am preparing myself (U9, Spanish woman, 46 years).
The users have a very positive view of the Internet as a place in which "there is everything", but they demonstrate fear in the face of the risks to their privacy, excessive dependence, and the coldness of the medium.

-I consider the Internet very positively because when I go online, although it may be only a small thing, I learn something. Each day I learn a little more (U3, Dominican male, 41 years).

-One loses a little humanity. And so, the defect which the Internet has for me is its coldness. ... and one must tread carefully (U6, French male, 62 years).

\section{-I consider the Internet very positively be-} cause when I go online, although it may be only a small thing, I learn something. Each day I learn a little more (Dominican male, 41 years)

These users have the sensation of knowing the basics, but they recognize that they need more digital literacy for which they would like to have training in the library.

-To give digital literacy workshops would be very good, because we come as people who don't know and there are even people with very little ICT knowledge (U5, Spanish male, 57 years).

-I miss a lot on Internet, I need a course in this because it makes me waste a lot of time... I don't like the Internet. I know it is marvelous, but it makes me waste time and I don't manage it well ... and so I am lost immediately... I prefer to look at something else ...so many things interest me that in the end I don't concentrate and I have a problem of disorganization and of being focused (U7, Spanish female, 41 years).
Users make very good suggestions for improvement. For example, that there ought to be more computers... which could have an expert in situ, helping when difficulties are found and who would be able to de-activate specific filters so as to be able to connect oneself to websites currently blocked: games online, like chess, auction websites, etc.

Globally, vulnerable users have varying levels of digital empowerment. When it is high (U1 or U9) it contributes in a greater measure to the reduction of social exclusion factors. Equally so, a very low level of digital empowerment is associated with a broad situation of exclusion and more difficult to deal with, as occurred in the case of U2. In whatever case, and for all of them including the least digitally competent, the $B R M$ is a medium of access and usage which is improving its information and digital capacities and practices.

\subsection{Social function of the BRM: Usage and interac- tion motivations}

Users manifest diverse motivations for gathering at the $B R M$--motivations related not only with functional factors (such as free access to computers and the Internet, the use of loan services, or reading the press), but also for psychological and socialization aspects linked to raising self-esteem and social relationships with other users and professional library staff. They feel as if they are in company with others, although in some cases there may only be scant real social interaction, and they draw attention to the feeling of solidarity generated between themselves if they are helped without having consult library personnel when they encounter IT difficulties.

-There are people who are homeless, or at best emerge from Caritas or wherever they passed the night and, instead of being on the street, they shelter here, and then they can grab a book or read the newspaper. What's more, there are many people who use the Internet to 
contact their acquaintances and to maintain family contact (TB9, Information).

-They use the computer a lot, to be in communication through Facebook or through the social networks, with their family, with people wherever they may be, and others to see films as a form of entertainment (TB11, Media room).

-Although you may have had a computer or Internet at home, you would come. That's clear... You would come by habit. And because I enjoy seeing people it pleases me to meet up with them. With my fellow countrymen, with Spanish people and with students who come here (U2, Dominican male, 41 years).

Their degree of digital empowerment contributes to reducing other factors of social exclusion including facilitating relationships and communication, accessing information, training, and leisure

At times, they make suggestions for increasing social relations:

-To have chess tables would be an attraction. If, instead of playing online there were two or three boards, people who enjoy playing chess could play in the library. (U4, Spanish male, 54 years).

-I would enjoy reading, theater groups for example; activities for people, every type of person, and particularly excursions. I don't know why they don't do it (U8, Moroccan woman, 44 years).

The positive effects quoted give evidence of, and explain, the social function which the BRM fulfills when its vulnerable users attribute certain values to the particular context which surrounds them, a diverse and respectful ambience (according to ethnicity and gender), aesthetically pleasing (light and colors), work and study space, and good treatment between professional library staff and users. These and other values mean that some consider the BRM "their second home". They are coming to recognize that to gather there is a habit difficult to break, even when they have similar resources in their own homes or in the residential refuge. This function stands out above all in users at major social risk. For them, their stay in the BRM supposes an emergence from their daily personal reality in which their vulnerability is evidenced in so far as they are: unemployed, without earnings, homeless, with scarcely any social or family relations.

-I'm a fan. It's a well-built library, visually speaking. It has a lot if light. And it's a tranquil place (U1, Brazilian man, 25 years).

-I stop thinking about all the bad things currently affecting me. Although in a Residence, I have been, and will continue, coming here (U2, Spanish man, 30 years).

-I'm hooked on the library. The best is the service to the people, the way they treat them, the courtesy that there is. I'm enchanted. And probably because they treat you well...are both cordial but formally polite at the same time (U7, Spanish woman, 41 years).

-Many users come to the library for the necessity of relating to others, for speaking, and for using it so as to avoid loneliness (TB5, Information and Reference).

-I'm hooked on the library. The best is the service to the people, the way they treat them, the courtesy that there is... I'm enchanted because they treat you well; they are cordial and formally polite at the same time (Spanish woman, 41 years)

-A relationship is established which I believe is, for many of these people, as if we were their family. Here they are as equal as the rest, and consequently the treatment which we give them is exactly the same as to the others (TB7, Information).

-Their treatment of us is exquisite which surprises us and we speak amongst ourselves that it has to be seen that, because of the difficulties that they have, many of these people live on the street. They have their education and their well-being in the library (TB16, Security).

Nevertheless, the highly positive evaluation of the users about the functioning of the $B R M$ as a place for socializing is not equally shared by other agents who participated in the investigation. Hence, although professional Librarians and onlookers agree about the good relations with, and treatment of, the users, particularly the vulnerable ones, on the subject of interaction they offer opposing views, depending on the scenario analyzed.

-They interacted very little among themselves, but positively with the library personnel, above all with those responsible for information and attention to the user, and with the library staff in media sections (06, Media \& Internet centre).

-A man of about 60, a Spaniard, is chatting with the security guard. He is very scruffy; in fact, he looks like a vagabond. Finally, he shakes hands and goes upstairs towards the $1^{\text {st }}$ floor to the media sections. (05, main Hall scenario).

-There are users who know one another and interact among themselves, while others don't. Among them, an air of amiability and courtesy can be observed $(08$, main Hall scenario).

-I don't perceive any bad attitudes among the users. Instead, it appears that there is complicity among some, perhaps because they share the same language or culture or have come together (04, Media rooms scenario).

Some professional librarians were interviewed and various observers have drawn attention to the fact that the interaction between users is rather scarce and very segregated, ac- 
cording to nationality, with certain reactionary elements towards them on the part of the more established groupings of library users.

-Almost always they speak amongst themselves, they are not accustomed to relate to 'normal' users (TB5, Information and Reference).

-Among themselves, there is a kind of spatial separation created, so as not to mix (TB10, Media rooms).

-The communication among the users was practically zero. Those who maintained a brief conversation did so mainly with people of their own nationality and in their mother tongue ( $\mathrm{O} 1$ and $\mathrm{O} 3$, comment on Media rooms scenario).

-The interior media room looks like a ghetto. From the first hour, by and

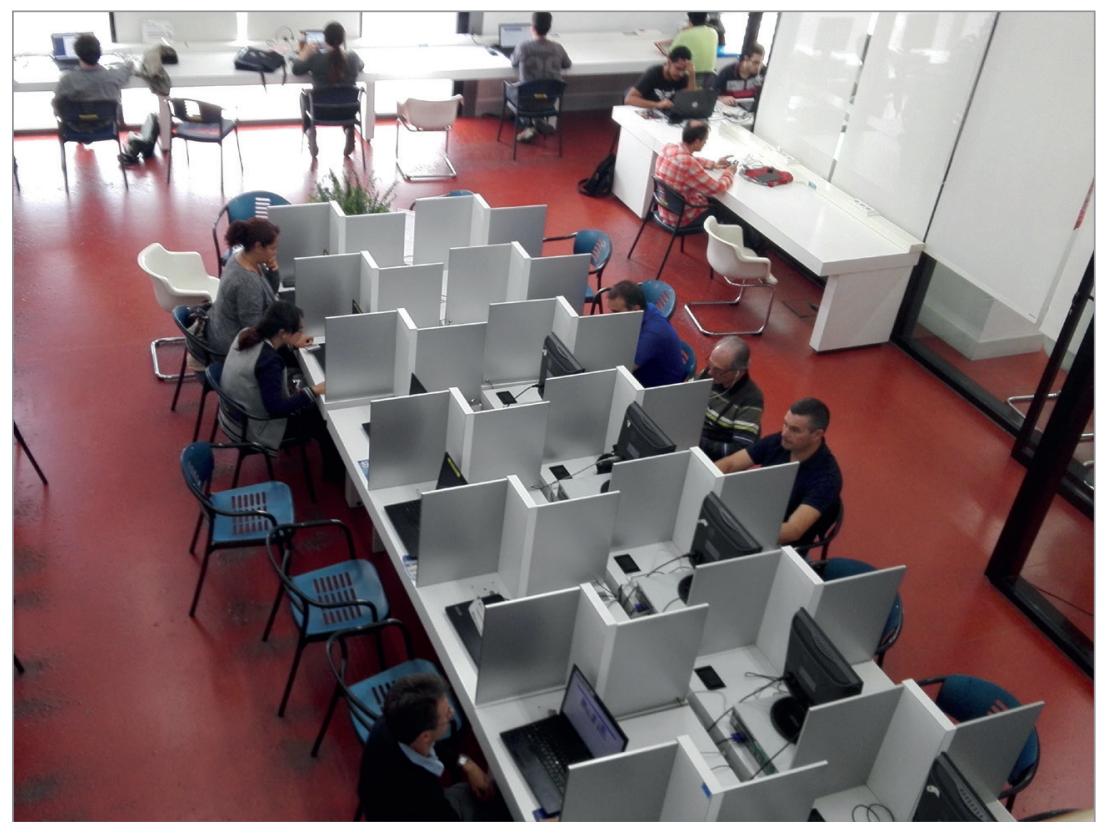

Computer and Internet Center (Interior Media Hall) large, it is occupied by immigrants and by homeless people. They appear to always occupy the same position and they get themselves to it in an almost mechanical manner. Because of this, perhaps it may be that other people avoid entering the interior media room (09, comment on Media rooms scenario).

-Some years ago, a user said to me, "Is this an NGO, or what?". Said because there were only foreigners there (TB8, Information).

-They spend hours on the Internet, foul-smelling people arrive, at times there are conflicts among members of the same nationality (TB6, Information).

For all of them, including the least digitally competent, the BRM (Biblioteca Regional de Murcia) is a medium of access which is improving their informational and digital capacities and practices

-In my opinion, perhaps the media rooms are the place where one is more able to sense that there may be segregation. Whilst the exterior media room is occupied by people of a regular user profile, the interior room is occupied by immigrants and by people of social exclusion (O2, comment on Media rooms scenario).

The differences between the discourses about socialization could be due to different perceptions about what is "normal" in social interaction. The groups at risk of exclusion usually have a low relationship index because their personal history is riddled with conflicts with family and friends and their self-esteem is low because of contributing factors of depression, mental illness, homelessness, unemployment, or addiction to drugs or alcohol. These difficulties cause them to positively value relationships which, for formally trained agents such as professional librarians or observers,

are inappropriate, tending to define them as segregated and non-participative. This is a perception, arising in part from the lack of comprehension by these observers, that social inclusion is a process which is arrived at in small steps, such as those which are taken in public spaces, for example libraries.

\section{Conclusions}

The $B R M$ is carrying out an important social function which is expanding with vulnerable groups, favoring the cohesion of being an open space with behavioral norms. Although users attend mainly because of free access to the Internet, they are turning it into a place for socialization--their "second home". Moreover, the library is contributing to the maintenance and improvement of the digital competencies of these vulnerable groups, verifying that those with a higher degree of digital empowerment have more possibilities of social advancement. Library services, which include reading and training workshops, support for studies, work environment orientation, cultural activities, book loans, facilitation of library spaces, computer equipment and connections, provide resources for digital, educational, and information inclusion; making them important for social inclusion.

In the $B R M$ different groups with different statuses and levels of digital empowerment gather. They come together in mutually respectful harmony, regardless of their gender, age, or nationality

In the $B R M$ different groups with different statuses, and different levels of digital empowerment, come together in a mutually respectful harmony, regardless of their gender, age, or nationality. The perceptions of library professionals, users, and observers relevant to the relationships and interaction which are generated in the library are diverse. The 
desired benefits of digital and social inclusion for vulnerable people are rated more highly by those very people than by those library professionals or observers.

The results show that $B R M$ is progressing towards a model better understood by disadvantaged groups in which it should continue advancing, since it is to be remembered that, in the Region of Murcia, $38.8 \%$ of the population is at risk of poverty or exclusion (Llano-Ortiz, 2016). On this theme, it would be interesting to take into account the Norms on library services for homeless persons which the IFLA (Winkelstein, 2016) has put together based on international experiences. Valuable practices to consider would be the developments in the Central Library of Zagreb (Bunić, 2015) and in that of Winston-Salem, North Carolina (Skinner, 2016). In both of these, staff have been trained in the characteristics of vulnerable users, taking into account the collaboration of some of them. Programs of digital literacy and workplace orientation have been carried out, beginning with real needs. Participative leisure programs are implemented and linked to reading, there is collaboration with the NGOs which service them, and they count on the assessment of social services' professionals to adapt the services in a way in which they contribute better to the integration of these users.

Although the library is increasing its social work, it should be recognized that it still only reaches a small part of the total population who find themselves vulnerable, namely $28.6 \%$ of the Spanish population (Llano-Ortiz, 2016). Currently the majority of the visits to public libraries continue to be carried out by those who have a level above the national socio-educational level, and the library is seldom visited by people of lesser resources. Because of that, and within the context of inequality, uncertainty and technological change, libraries must succeed in attracting a greater proportion of the citizenry at risk of exclusion, and to contribute to their integration and digital empowerment. This ought to be considered an opportunity and priority by a public enterprise which guarantees the effective right to information.

Although the library is increasing its social work, it should be recognized that it still only reaches a small part of the total population who find themselves vulnerable

\section{Notes}

1. "Library for everyone" was a program catering to the intercultural needs of local people and attracting Murcia Region's ethnic minorities and immigrants to the library, by means of contracting cultural mediators and offering services to these communities.

2. "Quitapesares" is a program for donating food to social welfare organizations which allows public library book borrowers who are overdue to return items borrowed and avoid penalties if they donate food to this program.

3. "Library and employment" is a program of work training for the unemployed.

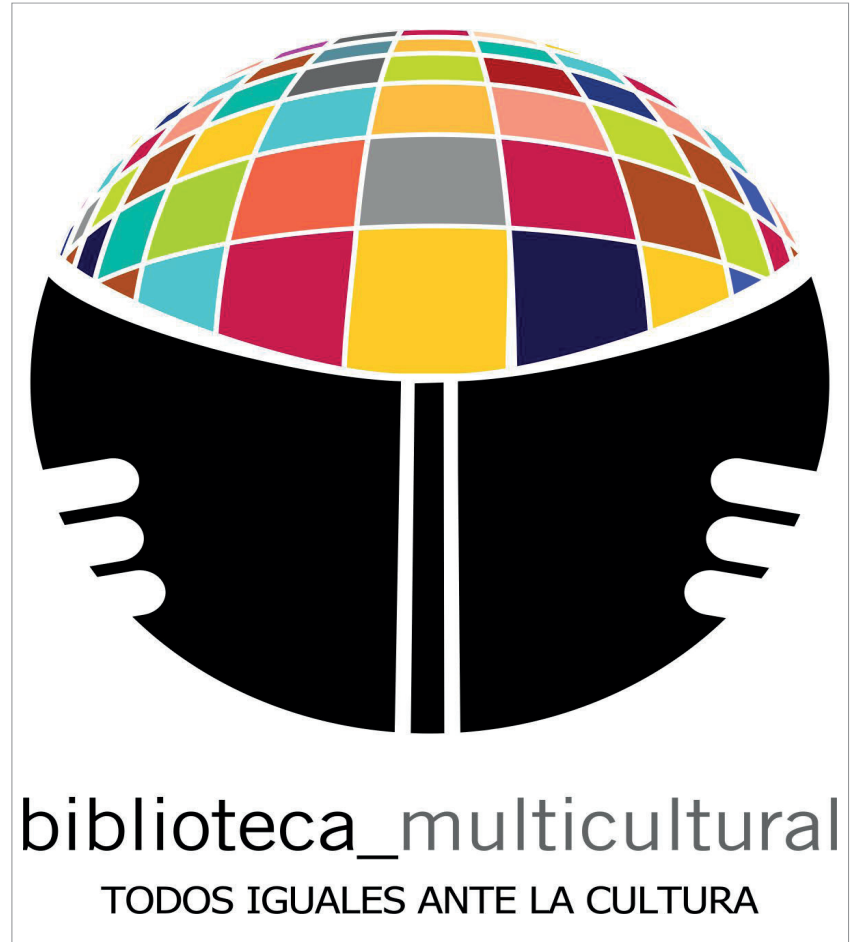

Biblioteca para todos program (see Note 1)

4. "What do you know" is a program in which library users offer training workshops, on a voluntary basis and in the library, on topics on which they are experts.

\section{References}

Biblioteca Regional de Murcia (2009). Memoria 2008. Murcia.

Biblioteca Regional de Murcia (2010). Encuesta de satisfacción de usuarios de la Biblioteca Regional de Murcia. Murcia. https://estaticocultura.carm.es/wbr/home/FIC20101203_051230. $p d f$

Biblioteca Regional de Murcia (2011). Memoria 2010. Murcia.

Biblioteca Regional de Murcia (2015). Memoria 2014. Murcia.

Bunić, Sanja (2015). "Why they need us and why we hesitate: The homeless in the library". En: IFLA World library and information congress. 81 $1^{\text {st }}$ IFLA General conference and assembly, Cape Town, South Africa. http://library.ifla.org/1261/1/100-bunic-en.pdf

Castel, Robert (2004). “Encuadre de la exclusión”. En: Karsz, Saül (ed.). La exclusión. Bordeando sus fronteras: definiciones y matices. Barcelona: Gedisa Editorial, pp. 55-86. ISBN: 8474329396

Castillo-Fernández, Javier (2010). “Biblioteca punto de empleo". En: Castillo-Fernández, Javier; Gómez-Hernández, José-Antonio; Quílez-Simón, Pedro (eds.). La biblioteca pública frente a la recesión, acción social y educativa. Murcia: Tres Fronteras, pp. 173-188. ISBN: 9788475645612

Europass (2015). Competencias digitales. Tabla de autoevaluación. Luxemburgo: European Commission.

http://europass.cedefop.europa.eu/es/resources/digitalcompetences 
Gallo-León, José-Pablo (2008). “Innovación en los servicios de bibliotecas públicas orientadas al usuario. El caso de la Biblioteca Regional de Murcia". El profesional de la informacion, v. 17, n. 2, pp. 144-154.

http://doi.org/10.3145/epi.2008.mar.03

Gallo-León, José-Pablo (2013). Prospectiva 2020. Las diez áreas que más van a cambiar en nuestras bibliotecas en los próximos años. Madrid: Consejo de Cooperación Bibliotecaria. http://www.mecd.gob.es/cultura-mecd/dms/mecd/culturamecd/areas-cultura/bibliotecas/mc/consejocb/grupos-detrabajo/21/estudio-prospectiva-2020.pdf

Gómez-Hernández, José-Antonio (2016). “Usuarios en vulnerabilidad social ¿por qué y para qué generar capital cultural desde la biblioteca?". Anuario ThinkEPI, v. 10, pp. 83-93. http://doi.org/10.3145/thinkepi.2016.13

Gómez-Hernández, José-Antonio; Saorín, Tomás (2015). "Trends in information literacy programmes to empower people and communities: Social technologies supporting new citizen needs". En: Passarelli, Brasilina; Straubhaar, Joseph; Cuevas-Cerveró, Aurora (eds.). Handbook of research on comparative approaches to the digital age revolution in Europe and the Americas. Hershey, Pensilvania, USA: IGI Global, pp. 315-330.

http://doi.org/10.4018/978-1-4666-8740-0

Gómez-Yáñez, José-Antonio (2014). Estudio Fesabid: El valor económico y social de los servicios de información: bibliotecas. Madrid: Fesabid.

http://www.fesabid.org/sites/default/files/repositorio/ fesabid-valor-economico-social-servicios-informacionbibliotecas.pdf

Hernández-Pedreño, Manuel (2008). “Pobreza y exclusión en las sociedades del conocimiento". En: Hernández-Pedreño, Manuel (coord.). Exclusión social y desigualdad. Murcia: Editum. ISBN: 9788483717752

http://www.um.es/documents/1967679/1967852/LibroExclusion-social-desigualdad-08.pdf/b3392fe8-ca07-44d48833-2a2124a3b190

Hernández-Sánchez, Hilario (2016). El valor de las bibliotecas. Estudio de impacto socioeconómico de las Bibliotecas de Navarra. Madrid: Consejo de Cooperación Bibliotecaria. http://www.elvalordelasbibliotecas.es/es/informe

IFLA (2014a). Declaración de Lyon sobre el acceso a la información y el desarrollo.

http://www.lyondeclaration.org/content/pages/lyondeclaration-es-v2.pdf

IFLA (2014b). Internet manifesto 2014.

http://www.ifla.org/publications/node/224?og=30

INE (2015). Estadística de bibliotecas 2014.

http://www.ine.es

Laparra-Navarro, Miguel; Obradors-Pineda, Anna; PérezEransus, Begoña; Pérez-Yruela, Manuel; Renes-Ayala, Víctor; Sarasa-Urdiola, Sebastián; Subirats, Joan; Trujillo-Carmona, Manuel (2007). "Una propuesta de consenso sobre el concepto de exclusión: implicaciones metodológicas". Re- vista española del tercer sector, n. 5, pp. 15-58.

https://dialnet.unirioja.es/servlet/articulo?codigo $=2376685$

Lison, Barbara; Reip, Natascha; Huysmans, Frank; Mount, Dan (2016). Research for CULT Committee: Public libraries. Their new role. Luxemburgo: Policy Department for Structural and Cohesion Policies.

http://www.europarl.europa.eu/thinktank/en/document. html?reference $=I P O L \_S T U(2016) 585882$

Llano-Ortiz, Juan-Carlos (2016). El estado de la pobreza. Seguimiento del indicador de riesgo de pobreza y exclusión social en España 2009-2015. Madrid: EAPN.

http://www.eapn.es/estadodepobreza

Ministerio de Educación Cultura y Deporte (2015). Bibliotecas públicas españolas en cifras.

http://www.mecd.gob.es/cultura-mecd/areas-cultura/ bibliotecas/mc/ebp/portada.html

Pimienta, Daniel (2009). “Digital divide, social divide, paradigmatic divide". International journal of information communication technologies and human development, v. 1, n. 1, pp. 33-48.

http://doi.org/10.4018/jicthd.2009010103

Punie, Yves; Brecko, Barbara (2014). Digcomp: Marco europeo de competencias digitales. Bruselas: Comisión Europea.

http://jakintza.eus/wp-content/uploads/DIGCOMP Donostia_ES-Rev.pdf

Raya-Díez, Esther (2007). “Exclusión social: indicadores para su estudio y aplicación para el trabajo social". Revista del Ministerio de Trabajo y Asuntos Sociales, n. 70, pp. 155-172. http://www.empleo.gob.es/es/publica/pub_electronicas/ destacadas/revista/numeros/70/Inf01.pdf

Reig-Hernández, Dolores (2012). Socionomía. Barcelona: Deusto. ISBN: 9788423412723

http://www.planetadelibros.com/libro-socionomia/65443

Skinner, Elizabeth J. (2016). "People experiencing homelessness: How libraries can be community collaborators and catalysts for change". In: IFLA World library and information congress 2016. Columbus, Ohio.

Subirats, Joan; Brugué, Joaquim; Gomà, Ricard (2002). "De la pobreza a la exclusión social: Nuevos retos para las políticas públicas". Revista internacional de sociología, n. 33, pp. 7-45.

https://goo.gl/OwMsMB

Togores, Rosa (2014). El valor de las bibliotecas públicas en la sociedad: El caso de la Red de Bibliotecas Municipales. Barcelona: Diputació Barcelona.

https://goo.gl/1jedbZ

Winkelstein, Julie-Ann (2016). "Overview of first draft of guidelines for library service to people experiencing homelessness and a brief overview of services to youth experiencing homelessness without parents or guardians". En: IFLA Council and general conference 2016. Columbus, Ohio: IFLA.

http://library.ifla.org/1494/2/147-winkelstein-en.pdf 


\section{Colección de libros de bolsillo \\ El profesional de la información (Editorial UOC)}

Últimos títulos publicados
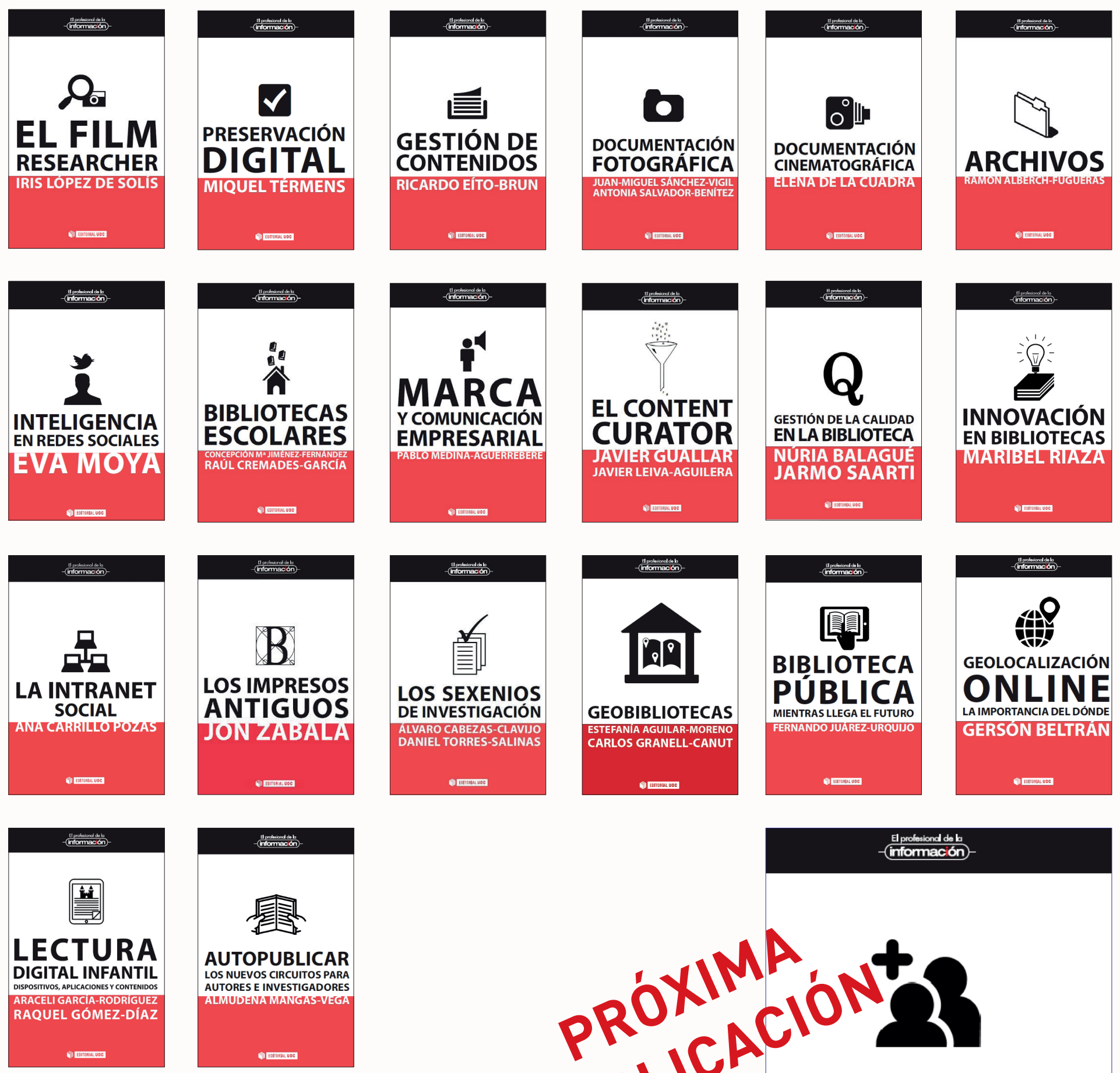

El profesional de la -información
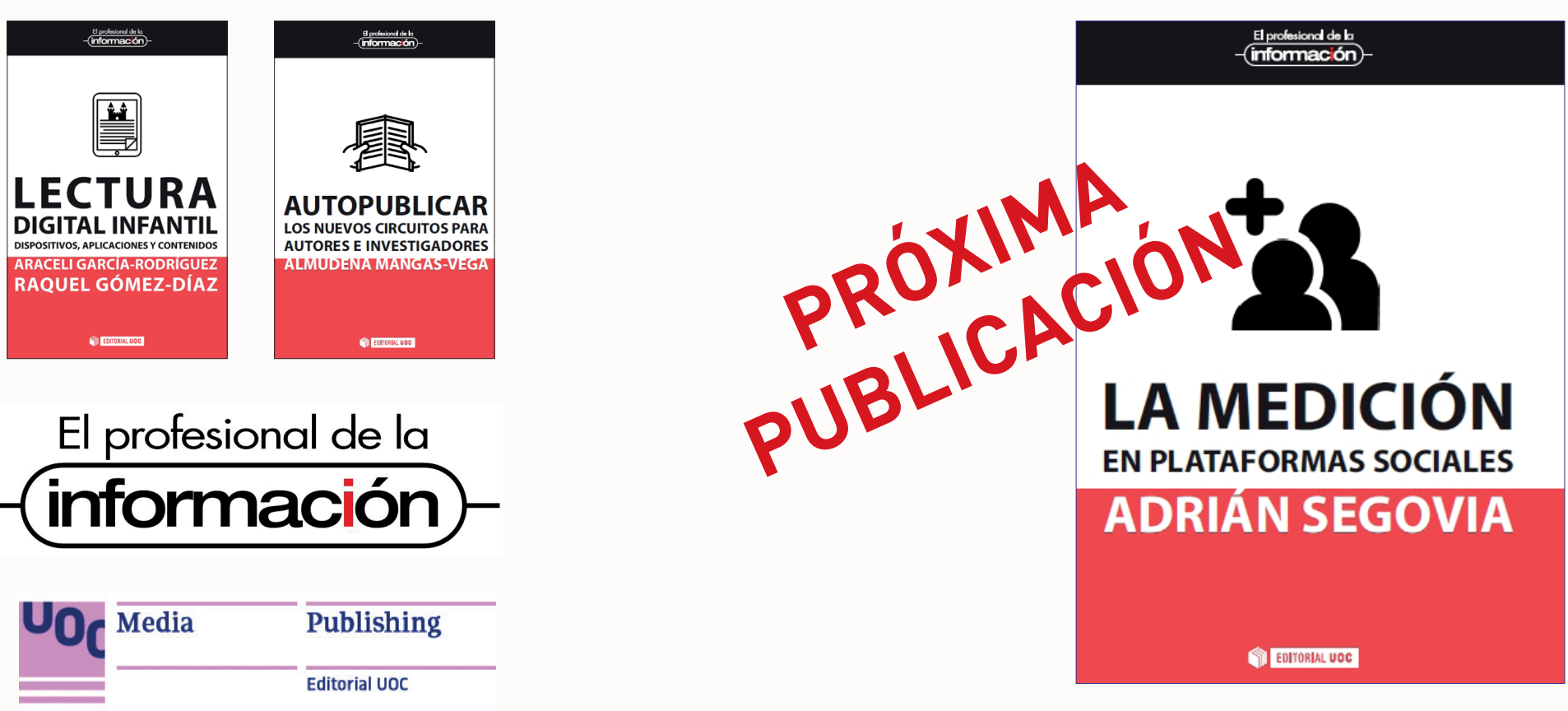

Más información: 